\title{
PENGARUH PERBANDINGAN ANTARA PENDAPATAN DAN BELANJA TERHADAP SURPLUS DAN DEFFISIT APBD KOTA DENPASAR TAHUN ANGGARAN 2017
}

\author{
Putu Novi Anesya Dewi A. , Ni Nyoman Ayu Ariningtyas, \\ Ni Putu Ermawati , Ni Kadek Puspita Sari \\ Jurusan Akuntansi, Universitas Pendidikan Ganesha, Singaraja, Bali, Indonesia
}

\begin{abstract}
Abstrak
Penelitian ini bertujuan untuk mengetahui perbandingan antara jumlah total pendapatan dengan jumlah total belanja pemerintah kota denpasar tahun anggaran 2017, apa yang termasuk urusan wajib pemerintah serta anggaran untuk urusan wajib pemerintah Kota Denpasar, seberapa besar perbandingan antara pendapatan dengan total belanja dari dinas kesehatan yang ada di Kota Denpasar, seberapa besarkah total surplus atau defisit dari anggaran pemerintah kota denpasar. Metode penelitian yang digunakan yaitu deskriptif, dengan jenis data primer dengan teknik pengumpulan data yang digunakan yaitu dokumentasi. Hasil dari penelitian ini bahwa penurunan kurs (nilai mata uang) juga akan meningkatkan defisit anggaran yang justru mempersulit penanganan defisit anggaran. Hal ini yang membuat cara ini tidak dapat diterapkan secara kontinyu dalam kebijakan ekonomi. Oleh karena itu, ajakan untuk mencapai stabilitas harga dan tukar selalu terfokus pada penyeimbangan pertumbuhan pertukaran uang, yang juga selalu terfokus pada keharusan penyeimbangan antara anggaran suatu negara dengan tidak menutupi defisit anggarannya dengan instrument moneter
\end{abstract}

Kata kunci: Perbandingan, Pendapatan, Belanja, Surplus, Deffisit

\begin{abstract}
This study aims to determine the comparison between the total amount of revenue with the total city government spending in Denpasar in the 2017 fiscal year, what is included in the compulsory affairs of the government and the budget for the obligatory affairs of the city of Denpasar, how big is the ratio between revenue and total expenditure from the health department in Denpasar City, how big is the total surplus or deficit of the Denpasar city government budget. The research method used is descriptive, with primary data types with data collection techniques used, namely documentation. The results of this study are that a fall in the exchange rate (the value of the currency) will also increase the budget deficit which makes it difficult to handle the budget deficit. This makes this method can not be applied continuously in economic policy. Therefore, the invitation to achieve price stability and exchange is always focused on balancing the growth of money exchange, which is also always focused on the necessity of a balance between a country's budget by not covering its budget deficit with monetary instruments
\end{abstract}




\section{Keywords : Comparison, Income, Expenditure, Deficit Surplus}

\section{Pendahuluan}

Negara Indonesia adalah Negara Kesatuan yang menganut asas desentralisasi dalam penyelenggaraan pemerintahan, hal ini terlihat dari pemberian kesempatan dan keleluasaan kepada daerah untuk menyelenggarakan Otonomi Daerah yang dilaksanakan oleh pemerintah daerah atau dengan kata lain daerah diberi keleluasaan untuk mengurus sendiri urusan pemerintahannya. Sebagaimana yang tertuang dalam bunyi pasal 18 ayat 2 Undang-Undang Dasar Negara Republik Indonesia Tahun 1945, yang berbunyi: "Pemerintah daerah provinsi, daerah kabupaten, dan kota mengatur dan mengurus sendiri urusan pemerintahan menurut asas otonomi dan tugas pembantuan." Sistem pemerintahan diatas terjadi karena Indonesia sedang berada di tengah masa transformasi dalam hubungan antara Pemerintah Pusat, Provinsi dan Kabupaten/Kota yang mana pemerintah daerah adalah merupakan perpanjangan tangan pusat didaerah. Namun meskipun demikian hal ini dapat memberi jalan bagi pemerintah daerah untuk mengatur secara penuh pelaksanaan rumah tangga dan dapat mengambil tanggung jawab yang lebih besar dalam memberikan pelayanan umum kepada masyarakat di daerah, untuk mengatur dan mengurus rumah tangganya sendiri[1]. Hal ini sesuai dengan amanat Pasal dalam Undang-Undang Dasar Negara Republik Indonesia diatas.Pelaksanaan sistem pemerintah daerah ini selain diamanatkan dalam Undang-Undang Dasar Negara Republik Indonesia Tahun 1945 juga diatur secara tegas dan jelas dalam UndangUndang Nomor 23 Tahun 2014 Tentang Pemerintah Daerah. Dengan dibentuknya UndangUndang Nomor 23 Tahun 2014 Tentang Pemerintah Daerah ini diharapkan dapat mengarahkan untuk mempercepat terwujudnya kesejahteraan masyarakat melalui peningkatan, pelayanan, dan pemberdayaan dan peran serta masyarakat serta daya saing daerah dengan memperhatikan prinsip demokrasi, pemerataan, keadilan, keistimewaan, dan kekhususan suatu daerah dalam Negara Kesatuan Republik Indonesia.

Menurut Peraturan Menteri Dalam Negeri Nomor 21 Tahun 2011 tentang Perubahan kedua atas Peraturan Menteri Dalam Negeri Nomor 13 Tahun 2006 tentang pedoman pengelolaan keuangan daerah, Keuangan Daerah adalah semua hak dan kewajiban daerah dalam rangka penyelenggaraan pemerintahan daerah yang dapat dinilai dengan uang termasuk didalamnya segala bentuk kekayaan yang berhubungan dengan hak dan kewajiban. Sementara pengelolaan keuangan daerah adalah keseluruhan kegiatan yang meliputi perencanaan, pelaksanaan, penatausahaan, pelaporan, pertanggungjawaban, dan pengawasan keuangan daerah tersebut. Pemegang Kekuasaan Pengelolaan Keuangan Daerah adalah kepala daerah yang karena jabatannya mempunyai kewenangan menyelenggarakan keseluruhan pengelolaan keuangan daerah.

Hak dan kewajiban daerah tersebut perlu dikelola dalam suatu sistem pengelolaan keuangan daerah. Pengelolaan keuangan daerah merupakan subsistem dari sistem pengelolaan keuangan Negara dan merupakan elemen pokok dalam penyelenggaraan pemerintah daerah. Pengelolaan keuangan daerah juga harus dilakukan dengan cara yang baik dan bijak agak keuangan daerah tersebut bisa menjadi efisien penggunaanya yang 
sesuai dengan kebutuhan daerah. Pemerintah Daerah wajib menyusun laporan keuangan yang terdiri Laporan Pelaksanaan. Anggaran dan Laporan Finansial. Laporan Pelaksanaan Anggaran meliputi Laporan Realisasi Anggaran (LRA) dan Laporan Perubahan SAL, sementara itu Laporan financial terdiri dari Neraca, Laporan Operasional (LO), Laporan Perubahan Ekuitas serta Laporan Arus Kas. Disamping itu SKPD harus menyusun Catatan atas Laporan Keuangan (CaLK).

Berdasarkan permasalahan diatas, adapun rumusan masalah yang dilakukan yaitu bagaimana Perbandingan Antara Jumlah Total Pendapatan Dengan Jumlah Total Belanja Pemerintah Kota Denpasar Tahun Anggaran 2017, apa Yang Termasuk Urusan Wajib Pemerintah Serta Anggaran Untuk Urusan Wajib Pemerintah Kota Denpasar, seberapa Besar Perbandingan Antara Pendapatan Dengan Total Belanja Dari Dinas Kesehatan Yang Ada Di Kota Denpasar, seberapa Besarkah Total Surplus Atau Defisit Dari Anggaran Pemerintah Kota Denpasar.

\section{Metode}

\section{Lokasi dan Waktu Penelitian}

Peneitian ini kami lakukan di Badan Pusat Statistik (BPS) Kota Denpasar. Jl. Mulawarman No.11, Denpasar. pada tanggal 3 November 2018 dan penelitian kedua kami lakukan pada tanggal 10 November 2018

\section{Jenis Penelitian}

Penulisan ini merupakan jenis penulisan deskkriptif, yaitu suatu jenis penulisan yang menghasilkan data deskriptif yang berupa kata - kata tertulis dari orang - orang dan pelaku yang diamati secara tidak langsung atau studi kasus tunggak dan dilakukan Dalam satu lokasi penelitian saja.

\section{Jenis Data}

Jenis data yang kami gunakan Dalam penelitian kali ini adalah jenis data primer. yaitu suatu jenis data yang didapatkan oleh peneliti secara langsung dari sumber penelitian. Dalam penelitian kami kali ini data primer yang kami dapatkan berupa Ringkasan anggaran pendapatan dan belanja daerah pemerintah Kota Denpaar tahun anggaran 2017.

\section{Teknik Pengumpulan Data}

Dokumentasi

Bahan yang termasuk Dalam jenis, bentuk, dan sifat ataupun tempat informasi direkam yang menyampaikan informasi berupa fakta atau informasi yang sebenarnya. Dalam penelitian ini data yang kami dapatkan adalah Ringkasan anggaran pendapatan dan belanja daerah pemerintah Kota Denpaar tahun anggaran 2017.

\section{Hasil dan Pembahasan}

\section{Perbandingan antara Jumlah Total Pendapatan dengan Jumlah Total Belanja pemerintah Kota Denpasar tahun anggaran 2017}

Jumlah total pendapatan pemerintah kota denpasar pada tahun anggaran 2017 terdiri dari beberapa jenis pendapatan serta dana -dana lain yang telah dikumpulkan menjadi satu. Dana-dana tersebut meliputi :

a. Pendapatan awal pemerintah kota denpasar pada tahun 2017 sejumlah Rp.1.917.638.279.068,33 
b. Pendapatan asli daerah (PAD) dengan jumlah pendapatan sebesar Rp.805.299.902.232,00. Dari total pendapatan asli daerah atau PAD terdiri dari beberapa jenis pendapatan yaitu pendapatan pajak daerah, pendapatan retribusi daerah, pendapatan hasil pengelolaan kekayaan daerah serta pendapatan lain-lain PAD yang sah.

c. Terdapat pendapatan yang diperoleh dari dana pertimbangan yang mencakup tentang dana bagi hasil pajak atau bagi hasil bukan pajak, dana alokasi umum, serta dana alokasi kusus dengan jumlah total pendapatan yang dihasilkan dari dana perimbangan mencapai angka sebesar Rp.913.883.187.890,00

d. Pendapatan yang diperoleh dari dana lain-lain pendapatan daerah yang sah, yang terdiri dari empat jenis dana yang meliputi :

- Dana bagi hasil pajak dari propinsi dan pemerintah daerah lainnya

- Dana penyesuaian dan otonomi khusus

- Bantua keuangan

- Dana transfer lainnya

Dari keempat dana tersebut mendapatkan total pendapatan sebesar Rp. 198.445.188.946,33. Jadi dari pendapatan yang didapatkan dari pendapatan asli daerah, dana perimbangan, serta dana lain-lain pendapatan daerah yang sah mendapatakan jumlah total pendapatan pemerintah kota denpasar pada tahun anggarn 2017 sebesar Rp. 1.917.638.279.068,33. Sedangkan dari data yang kami dapatkan bisa dilihat bahwa jumlah total belanja jauh lebih besar dibandingkan dengan pendapatan yang dieproleh dari pendapatan pemerintah kota denpasar pada tahun anggaran. Jumlah total belanja tersebut terdiri dari dua jenis belanja yaitu belanja tidak langsung dan belanja langsung.

Belanja tidak langsung terdiri dari tujuh jenis belanja yang masing-masing memiliki perbandingan yang cukup jauh yaitu belanja pegawai memiliki rentang jumlah belanja terbesar diantara jenis belanja tidak langsung lainnya yaitu mencapai angka $\mathrm{Rp}$. 782.708.052.708,15. Sedangkan enam jenis belanja langsung lainnya memiliki rata-rata belanja hanya sekitar puluhan milyar, enam jenis belanja tidak langsung tersebut terdiri dari :

a. Belanja hibah,

b. Belanja bantuan sosial

c. Belanja bagi hasil kepada propinsi /kabupaten/kota serta pemerintah desa

d. Belanja bantuan keuangan kepada propinsi/kabupaten/kota serta pemerintahan desa dan partai politik

e. Belanja tidak terduga

Sehingga dari ketrujuh jenis belanja tidak langsung tersebut jumlah totalnya menacapi Rp. 1.045.037.373.902,33. Kemudian terdapat belanja tidak langsung yang terdiri dari tiga jenis belanja yaitu belanja pegawai, belanja barang dan jasa, serta belanja modal dengan jumlah total biaa langsung yaitu Rp. 1.010.031.849.277,00. Jadi jumlah total belanja sudah mencapai angka sebesar Rp. 2.055.069.233.179,33.

Jadi kesimpulannya yaitu jumlah pendapatan yang didapatkan dari pemerintah kota denpasar pada tahun anggaran 2017 jumlahnya lebih kecil dibandingkan dengan jumlah total belanja yang telah dikeluarkan oleh pemerintah. Sehingga dari perbandingan antara jumlah pendapatan dengan jumlah total belanja menghasilkan surplus atau defisit sebesar Rp. 137.430.944.111,00 


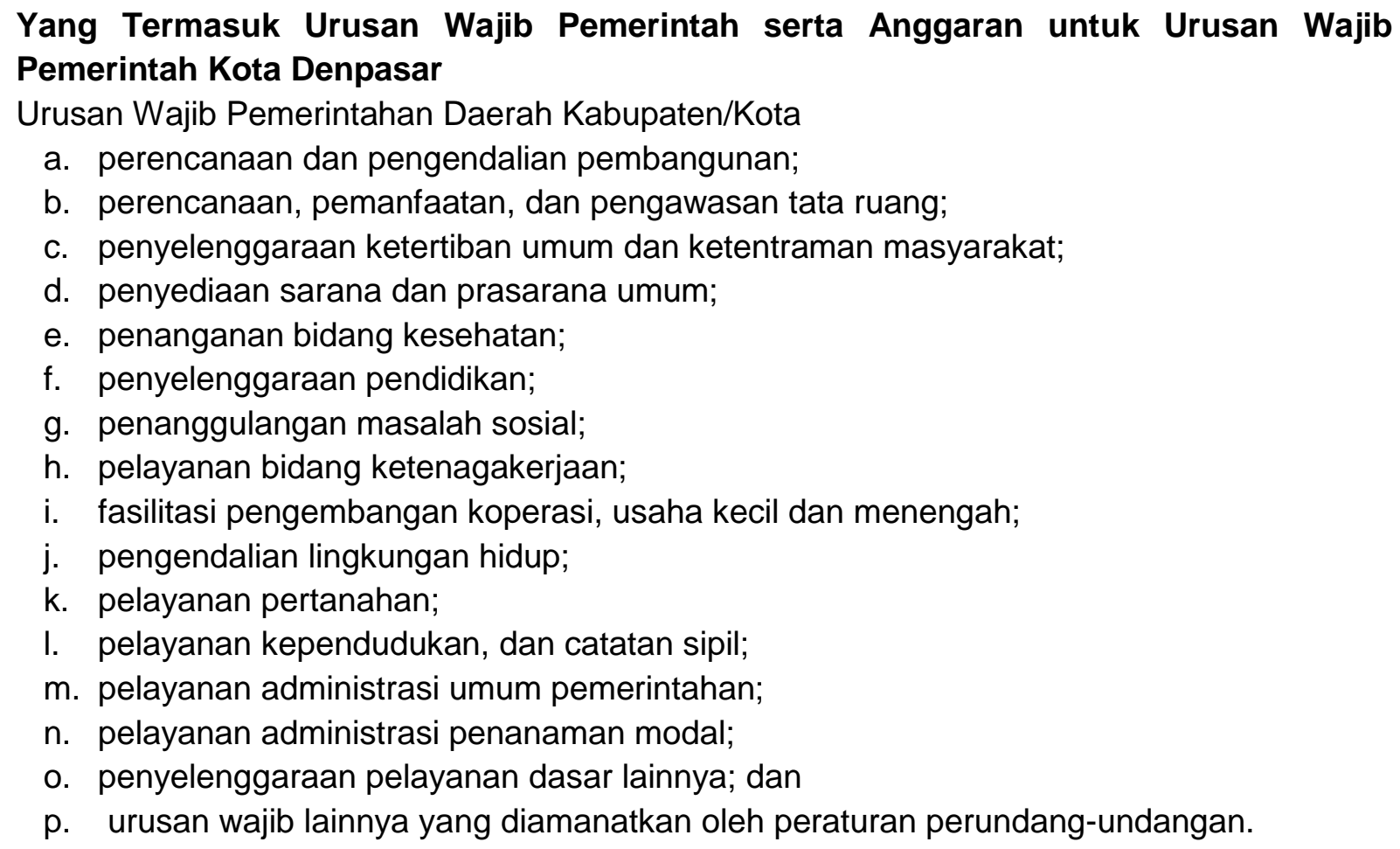

Adapun, yang menjadi urusan pilihan pemerintahan daerah, baik provinsi ataupun kabupaten/kota meliputi urusan pemerintahan yang secara nyata ada dan berpotensi untuk meningkatkan kesejahteraan masyarakat. Hal ini dilakukan sesuai dengan kondisi, kekhasan, dan potensi unggulan daerah yang bersangkutan. Jadi total pendapatan yang dihasilkan dari urusan wajib pemerintah yaitu sebesar Rp. 172.791.528.586,00. Sedangkan, anggaran belanja dari urusan wajib pemerintah tersebut yang terdiri dari belanja langsung dan tidak langsung berjumlah Rp. 3.028.231.400.893,14

\section{Seberapa Besar Perbandingan antara Pendapatan dengan Total Belanja dari Dinas Kesehatan yang Ada di Kota Denpasar}

Di dalam dinas kesehatan terdapat dua bidang yaitu dinas kesehatan biasa dan BLUD RSUD WANGAYA dengan total pendapatan yang lebih kecil dibandingkan dengan jumlah total belanja dari dinas kesehatan tersebut. Jumlah total pendapatan dari dinas kesehatan hanya menacapai angka Rp. 130.627.528.586,00. Sedangkan jumlah total pemblanjaan dari dinas kesehatan terdiri dari belanja tidak langsung sejumlah Rp. 131.711.064.900,00, serta belanja langsung dengan selisih sedikit lebih besar dari belanja tidak langsung yaitu sejumlah Rp. 147.249.528.196,00 sehingga total belanjanya berjumlah Rp. 278.960.593.096,00.

\section{Seberapa Besar Total Surplus atau Defisit dari Anggaran Pemerintah Kota Denpasar}

Defisit biasa terjadi ketika suatu organisasi (biasanya pemerintah) memiliki pengeluaran lebih banyak daripada penghasilan. Lawan dari defisit adalah surplus. Hal pertama yang harus dicatat adalah, munculnya kekurangan dalam pendanaan di banyak negara merupakan hal yang klasik. Pemerintah di banyak negara juga mengenal defisit anggaran, bahkan sebelum penemuan istilah anggaran umum. Dulu, negara meminjam dari 
pedagang dan rentenir saat dalam kondisi membutuhkan, khususnya untuk membiayai perang, seremoni dan festival kerajaan, dan menanggulangi bencana.

Perlu juga dipaparkan, terjadinya defisit anggaran diakibatkan oleh beberapa faktor penting: adakalanya ia terjadi karena anggaran yang memang kurang, dan adakalanya pula cara atau metode pembiayaan yang mengakibatkan defisit. Defisit berarti, pemerintah mengkonsumsi lebih dari jumlah pendapatannya yang kemudian biaya kekurangannya itu diambilkan dari pendapatan individu. Ini artinya, total permintaan terhadap barang dan jasa berlebih jika dibandingkan dengan total penawaran. Pengertian ini dengan asumsi bahwa masyarakat terhalangi dari perdagangan luar negeri yang menyebabkan seluruh konsumsi individu harus ditekan untuk memberi ruang bagi konsumsi pemerintah yang berlebih.

Jika defisit anggaran didanai melalui prosedur pinjaman publik dalam negeri, tekanan moneter dari total permintaan pemerintah terhadap harga tidak akan terjadi-setidaknya dalam teori-karena sarana pembayaran individu yang kelebihan berhasil di serap, dan dengan demikian inflasi mata uang tidak terjadi karena kebijakan tersebut. Adapun apabila defisit dibiayai oleh pinjaman Bank Sentral-penerbitan mata uang-maka tekanan inflasi harga mata uang mulai muncul sebagai akibat adanya alat pembayaran yang berlebih daripada penawaran yang ada. Adapun dalam sistem perekonomian yang terhubung dengan perdagangan internasional melalui ekspor dan impor, kelebihan konsumsi pemerintah dapat ditutupi oleh impor. Di sini, metode penanganan defisit juga berdampak besar terhadap konsekuensi yang muncul. Yaitu, apabila penanganan defisit anggaran ditutupi dengan penerbitan uang baru (ekspansi moneter) akan menyebabkan inflasi dan merosotnya nilai kurs mata uang lokal di hadapan mata uang asing.

Pada akhirnya, penurunan kurs (nilai mata uang) juga akan meningkatkan defisit anggaran yang justru mempersulit penanganan defisit anggaran. Hal inilah yang membuat cara seperti ini tidak dapat diterapkan secara kontinyu dalam kebijakan ekonomi. Oleh karena itu, ajakan untuk mencapai stabilitas harga dan tukar selalu terfokus pada penyeimbangan pertumbuhan pertukaran uang, yang juga selalu terfokus pada keharusan penyeimbangan antara anggaran suatu negara dengan tidak menutupi defisit anggarannya dengan instrumen moneter. Dari definisi surplus atau defisit diatas dan dilihat dari data ringkasan APBD pemerintah kota denpasar tahun anggaran 2017 mencapai jumlah Rp. 137.430.944.111

\section{Simpulan dan Saran}

\section{Simpulan}

1. Berdasarkan Perbandingan antara Jumlah Total Pendapatan dengan Jumlah Total Belanja pemerintahKota Denpasar tahun anggaran 2017 dapat disimpulkan bahwa jumlah pendapatan yang didapatkan dari pemerintah kota denpasar pada tahun anggaran 2017 jumlahnya lebih kecil dibandingkan dengan jumlah total belanja yang telah dikeluarkan oleh pemerintah. Sehingga dari perbandingan antara jumlah pendapatan dengan jumlah total belanja menghasilkan surplus atau defisit sebesar Rp. 137.430.944.111,00

2. Berdasarkan rumusan masalah kedua yaitu Yang Termasuk Urusan Wajib Pemerintah serta Anggaran untuk Urusan Wajib Pemerintah Kota Denpasar dapat disimpulkan bahwa Jadi total pendapatan yang dihasilkan dari urusan wajib pemerintah yaitu 
sebesar Rp. 172.791.528.586,00. Sedangkan, anggaran belanja dari urusan wajib pemerintah tersebut yang terdiri dari belanja langsung dan tidak langsung berjumlah Rp. 3.028.231.400.893,14

3. Berdasarkan rumusan masalah ketiga yaitu Seberapa Besar Perbandingan antara Pendapatan dengan Total Belanja dari Dinas Kesehatan yang Ada di Kota Denpasar dapat disimpulkan bahwa Jumlah total pendapatan dari dinas kesehatan hanya menacapai angka Rp. 130.627.528.586,00 Sedangkan jumlah total pemblanjaan dari dinas kesehatan terdiri dari belanja tidak langsung sejumlah Rp. 131.711.064.900,00, serta belanja langsung dengan selisih sedikit lebih besar dari belanja tidak langsung yaitu sejumlah Rp. 147.249.528.196,00 sehingga total belanjanya berjumlah Rp. 278.960.593.096,00

4. Berdasarkan rumusan masalah keempat yaitu Seberapa Besar Total Surplus atau Defisit dari Anggaran Pemerintah Kota Denpasar dapat dismpulkan bahwa penurunankurs (nilaimatauang) juga akan meningkatkan defisit anggaran yang justru mempersulit penanganan defisit anggaran. Hal inilah yang membuat cara seperti ini tidak dapat diterapkan secara kontinyu dalam kebijakan ekonomi. Oleh karena itu, ajakan untuk mencapai stabilitas harga dan tukar selalu terfokus pada penyeimbangan pertumbuhan pertukaran uang, yang juga selalu terfokus pada keharusan penyeimbangan antara anggaran suatu negara dengan tidak menutupi defisit anggarannya dengan instrument moneter. Dari definisi surplus atau defisit diatas dan dilihat dari data ringkasan APBD pemerintah kota denpasar tahun anggaran 2017 mencapai jumlah Rp. 137.430.944.111

\section{Saran}

1. Saran bagi pembaca atau masyarakat :

- Diharapkan pembaca dapat mengetahui tentang APBD kota Denpasar

- Diharapkan pembaca juga dapat mengetahui tentang besarnya surplus atau defisit dari APBD kota Denpasar

2. Saran bagi penulis

Jika terjadi kesalahan baik di penulisan kata maupun kesalahan dalam memaparkan materi, pembaca dapat memberikan kritik dan saran untuk penulis agar kedepannya penulis dapat memaparkan materi dengan baik dan benar.

\section{DaftarPustaka}

Mhariyanto. (2015). "Pembagian Urusan Pemerintahan antara Pemerintah Pusat dan Daerah Kabupaten/Kota". [Online]. Tersedia: http://blogmhariyanto.blogspot.com/2015/11/pembagian-urusan-pemerintahankonkuren.

Denpasar. (2015). "Sekretariat Daerah Kota Denpasar". [Online]. Tersedia: https://denpasarkota.go.id/assets subdomain/pengumuman. 
Jurnal IImiah Akuntansi dan Humanika, Vol. 7 No. 2, Agustus 2017

ISSN: 2599-2651

Ridawia. (2017) "Pengertian Surplus". [Online].

Tersedia:

http://ridawia.com/surplus-adalah/ 